\title{
In Pediatric Lymphoblastic Leukemia of B-Cell Origin, a Small Population of Primitive Blast Cells Is Noncycling, Suggesting Them to be Leukemia Stem Cell Candidates
}

\author{
ANDREAS HIRT, ANNE-MARIE SCHMID, ROLAND A. AMMANN, AND KURT LEIBUNDGUT \\ Department of Pediatrics [A.H., R.A.A., K.L.], Department of Clinical Research [A.H., A.M.S., K.L.], Bern University Hospital, University \\ of Bern, CH-3010 Bern, Switzerland
}

\begin{abstract}
Kinetic investigations in pediatric acute lymphoblastic leukemia (ALL) are based on all blast cells and, therefore, reflect the proliferative characteristics of the predominant immunophenotype of leukemic cells. Nothing is known about proliferation of immunologically defined rare subpopulations of leukemic cells. In this study, mononuclear cells from the bone marrow of 15 children with untreated CD $19^{+}$B-cell precursor ALL were examined for proliferative features according to the immunophenotype. After exclusion of highly proliferating residual normal hematopoietic cells, $\sim 3 \%$ of blast cells were $\mathrm{CD}_{1}{ }^{-}$and showed a low percentage of cells in S-phase assessed by the bromodeoxyuridine labeling index (BrdULI): median BrdU-LI, 0.19\% [interquartile range (IQR), 0.15$0.40 \%$ ]. In contrast, a median BrdU-LI of $7.2 \%$ (IQR, 5.7-8.8\%) was found for the major $\mathrm{CD} 19^{+}$blast cell compartment. Staining smears of sorted $\mathrm{CD} 19^{-}$cells for CD10 or CD34 revealed a small fraction of $\mathrm{CD} 19^{-} \mathrm{CD} 10^{-}$or $\mathrm{CD} 19^{-} \mathrm{CD} 34^{-}$blast cells. These cells were almost nonproliferating with a median BrdU-LI of $<0.1 \%$ (IQR, $0-0.2 \%)$. This proliferative behavior is suggestive of a stem/ progenitor cell function and, in addition, the low proliferative activity might render them more resistant to an antiproliferation-based chemotherapy. However, xenotransplantation experiments will be necessary to demonstrate a possible stem cell function. (Pediatr Res 69: 194-199, 2011)
\end{abstract}

$I^{n}$ pediatric B-cell precursor acute lymphoblastic leukemia (BCP-ALL), the majority of blast cells express the B-cell antigen CD19. However, a minor fraction of blast cells lack CD19 expression and, according to the current view of B-cell differentiation, correspond to a more immature cell population (1). Investigations on cell proliferation in pediatric ALL are usually based on the entire leukemic cell population in the bone marrow, and the results reflect the proliferative behavior of the predominant immunologically defined phenotype of blast cells. In light of the ongoing debate on the immunophenotype of leukemia stem cells (LSCs) in pediatric BCP-ALL (2), it was of interest to analyze the proliferative characteristics of ALL cells at different stages of immunophenotypic maturation. Usually, stem cells are characterized by proliferative quiescence or a very low proliferation rate. Because

Received July 26 2010; accepted October 12, 2010.

Correspondence: Andreas Hirt, M.D., Division of Pediatric Hematology/Oncology, University Children's Hospital, Inselspital, CH-3010 Bern, Switzerland; e-mail: andreas.hirt@insel.ch

Supported by the Foundation for Clinical and Experimental Cancer Research, Bern, Switzerland. actual treatment of ALL is mainly directed at proliferating cells, noncycling leukemic cells would preferentially escape such treatment and contribute to ALL relapse. Therefore, it would be of great interest to define a quiescent/low proliferating leukemic cell population in more detail. This study shows that in untreated BCP-ALL, immunophenotypic maturation of leukemic cells is paralleled by an increase in the proliferation rate and demonstrates the existence of a small population of nonproliferating leukemic cells with a very immature phenotype.

\section{METHODS}

Material. Bone marrow samples from 15 children (age, 2-16 y) with untreated BCP-ALL were obtained from diagnostic bone marrow aspiration. By diagnostic flow cytometry, the CD19 antigen was expressed on $97 \pm 3 \%$ of blast cells. The study was approved by the Ethics Committee of the University Children's Hospital Bern, and informed consent was obtained from the patients or their parents.

Cell sorting. Mononuclear bone marrow cells were isolated by Ficoll gradient centrifugation. To delineate $\mathrm{T}$ lymphocytes and precursor B cells, cells in suspension were stained with MAb against CD19 conjugated with fluorescein (FITC) and CD3 conjugated with phycoerythrin (PE; both from Becton Dickinson, Allschwil, Switzerland) and then separated by fluorescence-activated cell sorting (FACScan Becton-Dickinson) into $\mathrm{CD}^{+}$, $\mathrm{CD}_{19}{ }^{-}$, and $\mathrm{CD} 19^{+}$cell populations; in additional experiments, the distribution of CD19 fluorescence intensity was used to sort CD19+ cells into two subpopulations of equal size, one with low $\left(\mathrm{CD} 19^{+ \text {low }}\right)$ and the other with high $\left(\mathrm{CD} 19^{\text {+high }}\right)$ fluorescence intensity. In addition to samples of BCP-ALL, NALM-6 cells, a commercially available pre-B-cell line, was analyzed in the same manner.

Immunologic staining. The sorted cells were incubated in vitro with bromodeoxyuridine (BrdU) and, after preparation of cytocentrifuge smears, stained with an anti-BrdU antibody to enable detection of cells in the S-phase of the cell cycle (BrdU-labeling index, LI; BrdU Labeling and Detection Kit, Roche Diagnostics, Rotkreuz, Switzerland). In addition to BrdU, smears of sorted cells were also stained with MAb against CD34, CD10, myeloperoxidase, or glycophorin A (all from Becton Dickinson) and the alkaline:antialkaline phosphatase method (APAAP) as described earlier (3). In addition, cytocentrifuge smears of CD19 $9^{+ \text {low }}$ and CD19 ${ }^{\text {thigh }}$ cells were stained with a rabbit polyclonal antibody against the retinoblastoma protein phosphorylated at serine 608 (pRbSer608; Cell Signaling Technology, BioConcept, Allschwil, Switzerland) followed by an alkaline phosphatase conjugated goat antibody against rabbit immunoglobulins (goat anti-rabbit AP; Dako, Glostrup, Denmark).

DNA staining. To assess variations in the expression of the CD19 antigen during the different phases of the cell cycle, BCP-ALL cells and NALM-6

Abbreviations: ALL, acute lymphoblastic leukemia; BCP-ALL, B-cell precursor ALL; BrdU, bromodeoxyuridine; FACS, fluorescence-activated cell sorting; FDR, fractional death rate (number of cells lost by apoptosis per 24 hours); GPA, glycophorin A; IQR, interquartile range; LI, labeling index; LSC, leukemia stem cell; MPO, myeloperoxidase; $\boldsymbol{t}_{\mathrm{s}}$, DNA synthesis time 
cells in suspension were stained simultaneously with a FITC-conjugated monoclonal anti-CD19 antibody and with the DNA binding stain Hoechst 33342 (bisBenzimideH 33342 trichloride; Sigma Chemical Co.-Aldrich Chemie, Buchs, Switzerland) and then analyzed by the FACS.

In situ hybridization. As 5 of the 15 analyzed BCP-ALL samples expressed the ETV6-RUNX1 (TEL/AML1) fusion to confirm the leukemic origin of the analyzed cell populations, FISH evaluation for ETV6-RUNX1 rearrangement was performed on nuclei of sorted $\mathrm{CD} 19^{+}$and $\mathrm{CD} 19^{-}$cells with the LSI TEL/AML1 ES Dual Color Translocation Probe (Abbott Diagnostics, Baar, Switzerland) for TEL (ETV6) at 12p13 and AML1 (RUNX1) at $21 \mathrm{q} 22$.

Statistics. Because the data were nonnormally distributed, median and interquartile ranges (IQRs) were calculated. For statistical evaluations, the nonparametric Wilcoxon signed-rank test was used.

\section{RESULTS}

Patients. Clinical and laboratory data of 15 patients with untreated BCP-ALL are shown in Table 1.

Analysis of sorted cells. A representative gating and sorting of bone marrow cells from a child with untreated BCP-ALL is shown in Figure 1. This pattern was consistent with all 15 analyzed bone marrow samples. Sorted $\mathrm{CD} 19^{-} \mathrm{CD}^{+}$cells (gate P1) corresponded morphologically to normal, small, nonproliferating $\mathrm{T}$ lymphocytes. The majority of $\mathrm{CD} 19^{-} \mathrm{CD}^{-}{ }^{-}$cells (gate P2) had blast cell morphology; however, some erythroblasts and immature myeloid cells could be detected within this subpopulation. The CD19 antigen was expressed on $93.1 \%$ (IQR, 87.5-96.9\%) of mononuclear bone marrow cells corresponding morphologically to leukemic blast cells (Fig. 1A). The frequency and the BrdU-LI of the different sorted cell populations are shown in Table 2. As cells expressing the CD19 antigen had a significantly higher proliferative activity than $\mathrm{CD} 19^{-}$cells $(p<0.001$; Fig. 2 ), it was of interest to investigate the relation between the intensity of CD19 antigen expression and the proliferative activity within the $\mathrm{CD} 19^{+}$cell population. Therefore, $\mathrm{CD} 19^{+}$cells were sorted into $\mathrm{CD} 19^{+ \text {low }}$ (gate P3a) and CD19 ${ }^{\text {high }}$ subpopulations (gate P3b; Fig. $1 B$ ), the median value of cells in the DNA synthesis phase was significantly higher among cells with a high compared with those with a low CD19 antigen expression $(p<0.001$; Table 2). The difference in the proliferative behavior was confirmed by staining cell samples of sorted $\mathrm{CD} 19^{+ \text {low }}$ and $\mathrm{CD} 19^{\text {high }}$ leukemic blast cells with an antibody against the retinoblastoma protein that is phosphorylated at serine 608 (pRbSer608), a marker associated with proliferating cells (4). The median values for pRbSer608 positivity were $49 \%$ (IQR, 40-64\%) and 74\% (IQR, 66-85\%) for the $\mathrm{CD} 19^{+ \text {low }}$ and $\mathrm{CD} 19^{\text {+high }}$ blast cell populations, respectively, $(p=0.0022)$. To demonstrate a cell-cycle dependency of CD19 antigen expression, BCP-ALL samples as well as NALM-6 cells were assessed by FACS analysis for DNA content and CD19 fluorescence. As shown in Figure 3 for highly proliferating NALM-6 cells, the intensity of CD19 fluorescence increased from the G1 phase to the G2/M phase. Therefore, the difference in the proliferating characteristics between $\mathrm{CD} 19^{\text {low }}$ and $\mathrm{CD} 19^{\text {thigh }}$ leukemic cells suggests that up-regulation of the CD19 antigen expression occurs during transition through the cell cycle.

As 5 of the 15 analyzed ALL samples presented the $t(12 ; 21)$ chromosomal translocation to confirm the leukemic nature of sorted $\mathrm{CD} 19^{+}$and $\mathrm{CD} 19^{-}$cells, FISH analysis was performed in two representative ETV6/RUNX1 positive cases. The fusion signal could be detected in cell nuclei of $90-100 \%$ of $\mathrm{CD} 19^{+}$cells and $75-90 \%$ of $\mathrm{CD} 19^{-}$cells, respectively. Considering the presence of 5-10\% normal hematopoietic cells within the $\mathrm{CD} 19^{-}$cell compartment in these two ALL sam-

Table 1. Clinical and laboratory data of 15 patients with B-cell precursor ALL

\begin{tabular}{|c|c|c|c|c|c|c|c|}
\hline Patient & Age $(y)$ & Sex & WBC* & Diagnostic flow cytometry & Cytogenetics & FISH & $\mathrm{CR}$ \\
\hline 1 & 6.8 & $\mathrm{~F}$ & 67.3 & $\mathrm{CD}_{1} 9^{+}, 10^{+}, 34^{+}, \mathrm{CD}^{-} \mathrm{CD}^{-} 3^{-}, \mathrm{MPO}^{-}$ & Failed & ETV6-RUNX1- & Yes, $>3$ y \\
\hline 2 & 3.0 & $\mathrm{~F}$ & 37.4 & $\mathrm{CD} 9^{+}, 10^{+}, 34^{+}, \mathrm{CD}^{-} \mathrm{CD}^{-} 3^{-}, \mathrm{MPO}^{-}$ & $45 \mathrm{XY},-22$ & ETV6-RUNX1 ${ }^{+}$ & Yes, $>1$ y \\
\hline 3 & 3.6 & M & 26.2 & $\mathrm{CD} 19^{+}, 10^{+}, 34^{+}, \mathrm{CD}^{-} \mathrm{CD}^{-} 3^{-}, \mathrm{MPO}^{-}$ & $46, X Y$ & ETV6-RUNX1- & Yes, $>2$ y \\
\hline 4 & 7.3 & M & 30.2 & $\mathrm{CD}_{1} 9^{+}, 10^{+}, 34^{+}, \mathrm{CD}^{-} \mathrm{CD}^{-} 3^{-}, \mathrm{MPO}^{-}$ & $46 \mathrm{XY}$ & ETV6-RUNX1- & Yes, $>3$ y \\
\hline 5 & 15.8 & $\mathrm{~F}$ & 19.3 & $\mathrm{CD}_{1} 9^{+}, 10^{+}, 34^{+}, \mathrm{CD}^{-} \mathrm{CD}^{-} 3^{+}, \mathrm{MPO}^{-}$ & $46, \mathrm{XX}$ & ETV6-RUNX1- & Yes, $>3 \mathrm{y}$ \\
\hline 6 & 2.5 & $\mathrm{~F}$ & 182.0 & $\mathrm{CD} 19^{+}, 10^{+}, 34^{+}, \mathrm{CD}^{-} \mathrm{CD}^{-} 3^{-}, \mathrm{MPO}^{-}$ & $45 \mathrm{XX}, \operatorname{dic}(9 ; 12)(\mathrm{p} ? ; \mathrm{p} ?)$ & ETV6-RUNX1 ${ }^{+}$ & Yes, $>3 \mathrm{y}$ \\
\hline 7 & 1.8 & $\mathrm{~F}$ & 150.0 & $\mathrm{CD}_{1} 9^{+}, 10^{+}, 34^{+}, \mathrm{CD}^{-} \mathrm{CD}^{-} 3^{-}, \mathrm{MPO}^{-}$ & $45, \mathrm{XX}, \operatorname{dic}(9 ; 20)(\mathrm{p} 13 ; \mathrm{q} 11)$ & ETV6-RUNX1- & Yes, $>3$ y \\
\hline 8 & 10.5 & M & 5.1 & $\mathrm{CD} 9^{+}, 10^{+}, 34^{+}, \mathrm{CD}^{-} \mathrm{CD}^{-} 3^{-}, \mathrm{MPO}^{-}$ & $46, X Y$ & ETV6-RUNX1 ${ }^{+}$ & Yes, $>2 \mathrm{y}$ \\
\hline 9 & 14.3 & $\mathrm{~F}$ & 31.5 & $\mathrm{CD} 19^{+}, 10^{+}, 34^{+}, \mathrm{CD}^{-} \mathrm{CD}^{-} 3^{-}, \mathrm{MPO}^{-}$ & $\begin{array}{l}\text { 46, } X,-X, t(3 ; 12)(q 23 ; q 22) \\
\quad \operatorname{del}(6)(\mathrm{q} 13 \sim 14 \mathrm{q} 23) \\
\quad \operatorname{del}(11)(\mathrm{q} 22 \mathrm{q} 23),+22\end{array}$ & ETV6-RUNX1 ${ }^{-}$ & Yes, $>2$ y \\
\hline 10 & 2.5 & M & 52.6 & $\mathrm{CD} 19^{+}, 10^{+}, 34^{+}, \mathrm{CD}^{-} \mathrm{CD}^{-} 3^{-}, \mathrm{MPO}^{-}$ & Failed & ETV6-RUNX1- & Yes, $>3$ y \\
\hline 11 & 6.4 & M & 3.8 & $\mathrm{CD}_{1} 9^{+}, 10^{+}, 34^{+}, \mathrm{CD}^{-} \mathrm{CD}^{-} 3^{+}, \mathrm{MPO}^{-}$ & $\begin{array}{l}\text { 46, } \mathrm{XY},-21, \mathrm{t}(7 ; 8)(\mathrm{p} 13 ; \mathrm{p} 23) \\
\operatorname{add}(12)(\mathrm{p} 11.2)\end{array}$ & ETV6-RUNX1 ${ }^{-}$ & Yes, $>1$ y \\
\hline 12 & 13.0 & M & 3.1 & $\mathrm{CD}_{19}{ }^{+}, 10^{+}, 34^{+}, \mathrm{CD}^{-} \mathrm{CD}^{-} 3^{-}, \mathrm{MPO}^{-}$ & $\begin{array}{l}\text { 90-92, XXYY, der(1)(pter->1p13:: } \\
\text { 1q12->1cen::1cen->1qter)x2, t( } 2 ; 9) \\
\text { (p12;p21)x2,-3,-3,-12,-15,+21,+7 }\end{array}$ & ETV6-RUNX1 ${ }^{+}$ & Yes, $>3$ y \\
\hline 13 & 4.0 & $\mathrm{~F}$ & 6.9 & $\mathrm{CD} 19^{+}, 10^{+}, 34^{+}, \mathrm{CD}^{-} \mathrm{CD}^{-} 3^{-}, \mathrm{MPO}^{-}$ & $47, \mathrm{XX}+21$ & ETV6-RUNX1 ${ }^{+}$ & Yes, $>1$ y \\
\hline 14 & 16.7 & M & 12.9 & $\mathrm{CD}_{1} 9^{+}, 10^{+}, 34^{+}, \mathrm{CD}^{-} \mathrm{CD}^{-} 3^{-}, \mathrm{MPO}^{-}$ & $\begin{array}{l}59, \mathrm{XY},+\mathrm{Y},+2,+\operatorname{der}(2) \mathrm{t}(2 ; 5)(\mathrm{q} ? 21 ; \\
\mathrm{q} ? 11.2),+4,+\operatorname{der}(6) \mathrm{t}(6 ; 7)(\mathrm{p} 11 ; \mathrm{q} 11.2) \\
\quad-7,+8, \mathrm{t}(9 ; 22)(\mathrm{q} 34 ; \mathrm{q} 11.2),+14+15,+15, \\
+18,+21,+21,+\operatorname{der}(22) \mathrm{t}(9 ; 22)\end{array}$ & $\begin{array}{l}\text { ETV6-RUNX1-; } \\
\text { BCR-ABL1 }{ }^{+}\end{array}$ & Yes, $<1$ y \\
\hline 15 & 2.3 & $\mathrm{~F}$ & 26.5 & $\mathrm{CD}_{19}{ }^{+}, 10^{+}, 34^{+}, \mathrm{CD}^{-} \mathrm{CD}^{-} 3^{-}, \mathrm{MPO}^{-}$ & $\begin{array}{l}54, \mathrm{XX},+\mathrm{X},+4,+6,+14,+17,+18 \\
\quad+21,+21\end{array}$ & ETV6-RUNX1 ${ }^{-}$ & Yes, $<1$ y \\
\hline
\end{tabular}

* White blood cell count at diagnosis.

$\mathrm{CR}$, complete remission. 

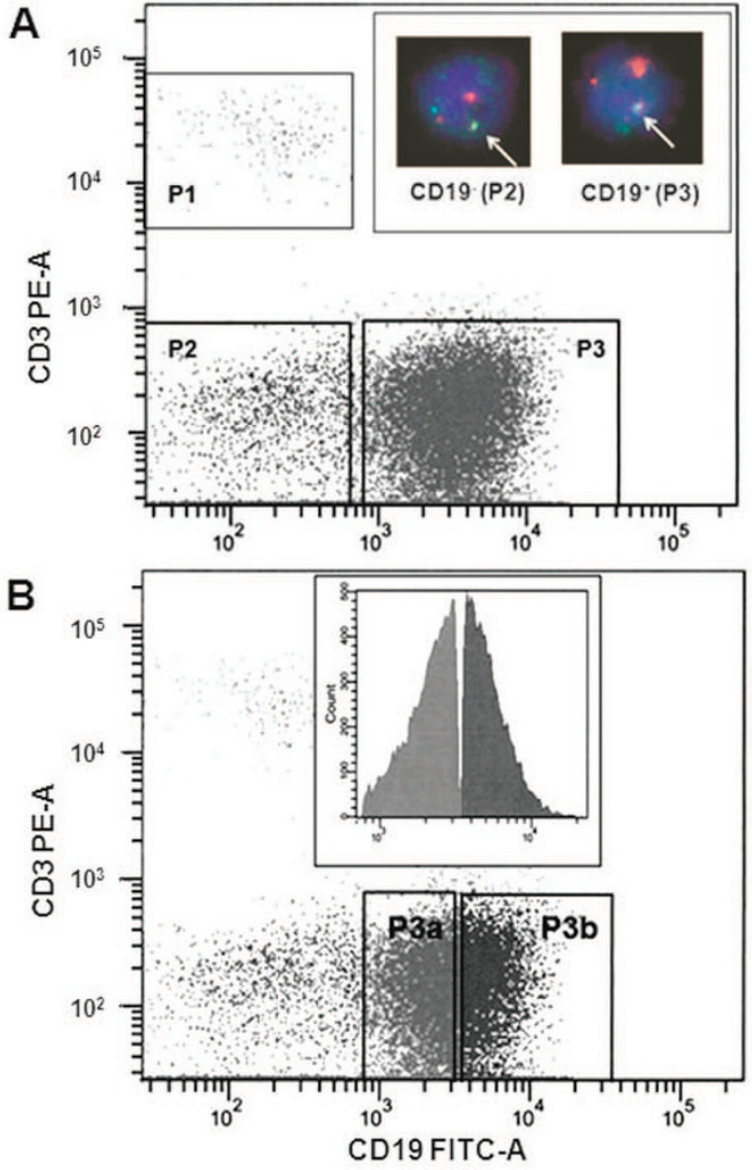

Figure 1. Gating and sorting of mononuclear bone marrow cells in untreated BCP-ALL. (A) Cells stained with fluorochrome-labeled monoclonal anti$\mathrm{CD}^{-} \mathrm{PE}$ and anti-CD19 ${ }^{-}$FITC antibodies were sorted into $\mathrm{CD} 3^{+} \mathrm{CD} 19^{-}$ cells (gate P1), $\mathrm{CD}_{3}{ }^{-} \mathrm{CD} 19^{-}$cells (gate $\mathrm{P} 2$ ), and $\mathrm{CD}_{3}{ }^{-} \mathrm{CD} 19^{+}$cells (gate $\mathrm{P} 3)$. Inset: FISH analysis of sorted $\mathrm{CD} 19^{+}$and $\mathrm{CD} 19^{-}$cells in a representative ETV6/RUNX1 positive case with the LSI TEL/AML1 ES Dual Color Translocation Probe; arrows indicate fusion signals. $(B) \mathrm{CD} 19^{+}$cells were further subdivided into cell populations with low (gate P3a) and high (gate P3b) antigen expression. Inset: Distribution of CD19 fluorescence intensity.

Table 2. Frequency and proliferation of sorted bone marrow cells in $B C P-A L L(n=15)$

\begin{tabular}{ccc}
\hline Gate & Frequency $(\%)$ & BrdU-LI $(\%)$ \\
\hline P1 $\left(\mathrm{CD}^{+}{ }^{+} \mathrm{CD} 19^{-}\right)$ & $3.3(1.6-10.8)$ & $0(0-0.04)$ \\
P2 $\left(\mathrm{CD} 3^{-} \mathrm{CD}^{-}\right)^{*}$ & $2.5(2.1-2.9)$ & $0.7(0.5-1.3)$ \\
P3 $\left(\mathrm{CD} 3^{-} \mathrm{CD}^{+} 9^{+}\right)$ & $93.1(87.5-96.9)$ & $7.2(5.7-8.8)$ \\
P3a $\left(\mathrm{CD} 3^{-} \mathrm{CD}^{+} 9^{+ \text {low }}\right)$ & $45.2(43.6-48.3)$ & $2.9(1.7-3.5)$ \\
P3b $\left(\mathrm{CD} 3^{-} \mathrm{CD} 19^{\text {high }}\right)$ & $47.9(44.8-49.5)$ & $8.9(6.1-11.0)$ \\
\hline
\end{tabular}

Values are represented as median (IQR).

* $\mathrm{CD} 3^{-} \mathrm{CD} 19^{-}$cells contain blast cells and residual normal hematopoietic cells.

ples, the leukemic nature of $\mathrm{CD}_{1} 9^{-}$cells with blast cell morphology was confirmed (Fig. 1A, inset).

Residual normal hematopoietic cells. The overall BrdU-LI of the $\mathrm{CD} 19^{-} \mathrm{CD}^{-}$cell compartment was $0.7 \%$ (IQR, 0.5$1.3 \%$ ). However, this was also due to residual normal hematopoietic activity within this compartment of bone marrow cells. Therefore, to delineate normal cycling hematopoietic cells, cytocentrifuge smears of sorted $\mathrm{CD} 19^{-} \mathrm{CD}^{-}$bone marrow cells were stained either with a MAb against myelo-

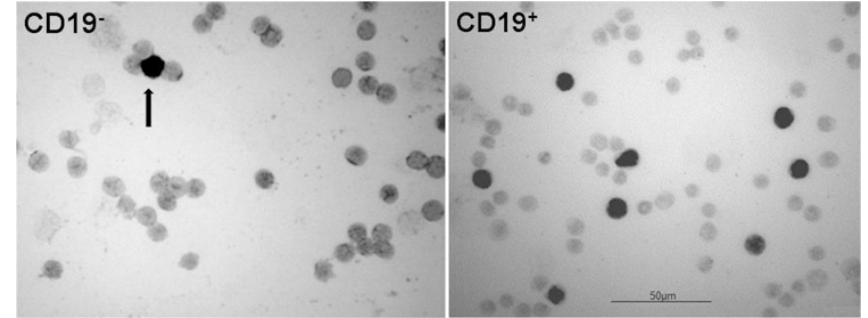

Figure 2. BrdU-LI of sorted $\mathrm{CD} 19^{-}$and $\mathrm{CD} 19^{+}$leukemic cells. In sorted $\mathrm{CD}^{-} 9^{-}$cells, a single black staining BrdU positive cell (arrow) can be seen (left panel); in $\mathrm{CD} 19^{+}$cells, 8 BrdU positive cells are detectable (right panel).

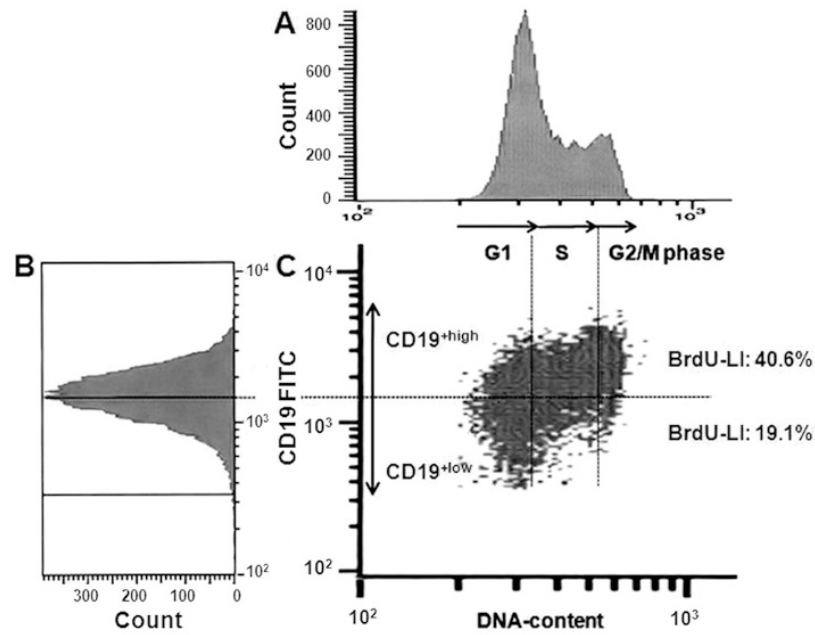

Figure 3. CD19 antigen expression during the cell cycle in NALM-6 cells. (A) Distribution of DNA content; $(B)$ distribution of CD19 fluorescence intensity, arbitrarily separated into low and high fluorescence by a line drawn through the peak of the distribution curve; and (C) CD19 fluorescence intensity according to the DNA content.

peroxidase (MPO) or a MAb against glycophorin A (GPA), in combination with an anti-BrdU-antibody. This procedure allowed to assess the relative frequencies and the BrdU-LI of residual myeloid and erythroid cells. After excluding these normal cells from further analysis, the relative frequency and the BrdU-LI value of the remaining leukemic blast cells was calculated. Within the $\mathrm{CD} 19^{-} \mathrm{CD}^{-}$bone marrow cell population, a median of $93.2 \%$ (IQR, 88.0-97.4\%) were blast cells with a BrdU-LI of $0.19 \%$ (IQR, 0.15-0.40\%), $2.9 \%$ (IQR, 1.6-6.8\%) were residual normal myeloid cells staining positive for MPO with a BrdU-LI of $14.7 \%$ (IQR, 9.4-22.5\%), and 2.2\% (IQR, 0.9-5.6\%) were erythroid cells staining positive for GPA with a median BrdU-LI value of $6.8 \%$ (IQR, $1.8-11.5 \%$ ). Of all BrdU positive S-phase cells within the $\mathrm{CD} 19^{-} \mathrm{CD}^{-}$cell compartment, $64 \%$ were $\mathrm{MPO}^{+}$and $24 \%$ were $\mathrm{GPA}^{+}$; therefore, only $12 \%$ of S-phase cells corresponded to leukemic blast cells. This fact emphasizes the importance of recognizing residual normal hematopoietic cells in kinetic investigations of the $\mathrm{CD} 19^{-}$leukemic cell compartment.

Leukemic CD19- subpopulations. To further analyze the CD19 ${ }^{-}$blast cell compartment, the expression of CD34 or CD10, early markers in B-cell differentiation, was investigated. Individual cytocentrifuge smears of sorted $\mathrm{CD} 19^{-} \mathrm{CD}^{-}$cells were stained for $\mathrm{BrdU}$ in combination with 
Table 3. Frequency and proliferation of immunologically defined blast cell populations after exclusion of normal residual hematopoietic cells $(n=15)$

\begin{tabular}{ccc}
\hline Immunophenotype & Frequency $(\%)$ & BrdU-LI $(\%)$ \\
\hline All leukemic cells & 100 & $7.1(5.3-8.1)$ \\
$\mathrm{CD} 19^{+}$leukemic cells & $97.7(96.8-98.5)$ & $7.2(5.7-8.8)$ \\
$\mathrm{CD} 19^{-}$leukemic cells & $2.6(1.9-3.2)$ & $0.19(0.15-0.40)$ \\
$\mathrm{CD} 19^{-} \mathrm{CD} 34^{+} *$ & $1.4(0.6-2.8)$ & $0.2(0.1-0.4)$ \\
$\mathrm{CD} 19^{-} \mathrm{CD} 34^{-} *$ & $0.8(0.5-1.6)$ & $<0.1(0-0.1)$ \\
$\mathrm{CD} 19^{-} \mathrm{CD} 10^{+} \dagger$ & $1.2(0.6-2.5)$ & $0.3(0-0.7)$ \\
$\mathrm{CD} 19^{-} \mathrm{CD} 10^{-} \dagger$ & $1.3(0.4-2.0)$ & $<0.1(0-0.2)$ \\
\hline
\end{tabular}

Values are represented as median (IQR).

* CD19- blast cells were subdivided according to CD34 antigen expression.

$\dagger \mathrm{CD} 19^{-}$blast cells were subdivided according to CD10 antigen expression.

one of the following markers: CD34, CD10, MPO, or GPA. The relative size and the BrdU-LI of $\mathrm{CD} 19^{-} \mathrm{CD} 34^{+}$or $\mathrm{CD} 19^{-} \mathrm{CD} 34^{-}$and $\mathrm{CD} 19^{-} \mathrm{CD} 10^{+}$or $\mathrm{CD} 19^{-} \mathrm{CD} 10^{-}$leukemic blast cell populations, as well as that of normal $\mathrm{MPO}^{+}$ and $\mathrm{GPA}^{+}$cells, could be defined. Among $\mathrm{CD} 19^{-} \mathrm{CD}^{-}$cells, $65 \%$ (IQR, 25-80\%) were CD $34^{+}$and $62 \%$ (IQR, 24-84\%) $\mathrm{CD} 10^{+}$. After exclusion of residual normal hematopoietic cells, the relative size of the different blast cell compartments, which is defined by the immunophenotype, and their BrdU-LI is shown in Table 3. The percentage of S-phase cells within the $\mathrm{CD} 19^{-} \mathrm{CD} 34^{+}$and $\mathrm{CD} 19^{-} \mathrm{CD} 10^{+}$subpopulations was comparably low in the range of $0.2-0.3 \%$. The blast cell populations with an immunophenotype of either $\mathrm{CD} 19^{-} \mathrm{CD} 34^{-}$or $\mathrm{CD} 19^{-} \mathrm{CD} 10^{-}$were almost all nonproliferating. Because of the extremely low proliferative activity, it was difficult to assess the exact BrdU-LI value of these two leukemic cell populations with the methods used, and a sampling error had to be taken into account. Nevertheless, the results clearly show that in BCP-ALL, the BrdU-LI of leukemic blast cells decreases with increasing immaturity of the blast cell population. The BrdU-LI of CD $19^{+}$blast cells was significantly higher than that of $\mathrm{CD} 19^{-}$blast cells $(p<0.001)$, within the $\mathrm{CD} 19^{-}$ blast cell population $\mathrm{CD} 34^{+}$or $\mathrm{CD} 10^{+}$cells had a significantly higher proliferation rate than the $\mathrm{CD} 34^{-}$or $\mathrm{CD} 10^{-}$ blast cells $(p=0.0320)$.

Kinetic calculations. To assess the influence of the different BrdU-LI values of CD19+ and CD19- leukemic blast cells on the expansion of the total malignant cell population, we calculated the doubling time $\left(t_{\mathrm{d}}\right)$ of these two leukemic subpopulations, i.e. the time required to double their cell number. For this calculation, we used a median DNA synthesis time $\left(t_{\mathrm{s}}\right)$ of $18.8 \mathrm{~h}$ (IQR, 17.5-20.2 h) and a fractional death rate (FDR), i.e. the percentage of leukemic cells dying by apoptosis per day, of $2.4 \%$ (IQR, 1.3-3.7\%), as described in earlier work on BCP-ALL $(5,6)$. Because these investigations have been done on the entire leukemic cell population, the values reported may be correct for the bulk of CD19 ${ }^{+}$blast cells, but not for the rare $\mathrm{CD} 19^{-}$leukemic cells. Because normal terminal deoxynucleotidyl transferase (TdT) positive lymphoid precursor cells in the bone marrow also showed a $t_{\mathrm{s}}$ of $18 \mathrm{~h}(5)$, we used this value for both the $\mathrm{CD} 19^{+}$and $\mathrm{CD} 19^{-}$leukemic cell populations. For $\mathrm{CD} 19^{-}$blast cells, which have low prolifer-
Table 4. Kinetic calculations for $\mathrm{CD} 19^{+}$and $\mathrm{CD} 19^{-}$leukemic blast cell populations after exclusion of normal residual hematopoietic cells $(n=15)$

\begin{tabular}{|c|c|c|}
\hline & $\mathrm{CD}_{19}{ }^{+}$blast cells & $\mathrm{CD} 9^{-}$blast cells \\
\hline BrdU-LI (\%) & $7.2(5.7-8.8)$ & $0.19(0.15-0.40)$ \\
\hline FBR/day $(\%)^{*}$ & $9.1(7.2-11.2)$ & $0.24(0.20-0.52)$ \\
\hline FDR/day $(\%) \dagger$ & $2.4(1.3-3.7)$ & 0 \\
\hline GR/day $(\%) \neq$ & $6.7(4.8-8.8)$ & 0.24 \\
\hline Doubling time $(\mathrm{d}) \S$ & $10.7(8.2-14.9)$ & $294(135-354)$ \\
\hline
\end{tabular}

Values are represented as median (IQR).

$*$ FBR (fractional birth rate) $=$ BrdU-LI/DNA synthesis time $\times 24$.

$\dagger$ FDR (fractional death rate) $=$ number of apoptotic cells in $\% \times 24 / 6$.

$\$$ GR (growth rate) $=$ FBR minus FDR.

$\S$ Doubling time $\left(t_{\mathrm{d}}\right)=\log 2 / \log \{1+\mathrm{NGR} / 100\}$.

ative activity, the FDR was set to $0 \%$. This resulted in doubling times in the range of $1.5 \mathrm{wk}$ for $\mathrm{CD} 19^{+}$blast cells and 10 mo for $\mathrm{CD}_{19}{ }^{-}$blast cells $(p<0.001$; Table 4$)$. Recalculating with a variable DNA synthesis time between 12 and $18 \mathrm{~h}$ and a FDR between 0 and $0.1 \%$ for $\mathrm{CD} 19^{-}$blast cells resulted in a doubling time between 5 and $12 \mathrm{mo}$. All these calculations are based on an assumed execution phase of apoptosis in leukemic cells of $6 \mathrm{~h}$ (6). Taking this value, a FDR of $0.24 \%$ in $\mathrm{CD}_{19^{-}}$leukemic cells $\left(t_{\mathrm{s}}\right.$ set to $\left.18 \mathrm{~h}\right)$ would result in a population without growth ( $t_{\mathrm{d}}$ to infinity). Assuming values between 3 and $8 \mathrm{~h}$ for the duration of the execution phase of apoptosis, the percentage of apoptotic cells resulting in a FDR of $0.24 \%$ would vary between 0.03 and $0.08 \%$. These calculated values suggest that the number of apoptotic cells within the $\mathrm{CD} 19^{-}$leukemic cell compartment should be very small; otherwise, this cell population would disappear.

\section{DISCUSSION}

The simultaneous immunocytochemical staining of sorted cell populations for surface markers and BrdU incorporation permits a combined assessment of immunophenotype and cell proliferation and, in addition, an evaluation of cell morphology. However, in contrast to an examination of cell suspensions by flow cytometry, staining a single smear with more than two immunologic markers was not feasible. To overcome this methodological restriction, staining with different markers was performed on separate cell smears. Using this technique, it was possible to assess the relative size and the proliferative characteristics of blast cell compartments with different immunophenotypes. For the assessment of the BrdU-LI in $\mathrm{CD}^{-} 9^{-}$subpopulations, it was assumed that residual normal $\mathrm{MPO}^{+}$myeloid cells and $\mathrm{GPA}^{+}$erythroblasts would lack CD34 or CD10 antigen expression. Accordingly, only the compartments of $\mathrm{CD}_{1} 9^{-} \mathrm{CD} 34^{-}$and $\mathrm{CD} 19^{-} \mathrm{CD} 10^{-}$cells were corrected for contaminating residual normal hematopoietic activity. This may hold true for CD10 antigen expression, however, some immature myeloid cells could express the CD34 antigen and therefore would contribute to the proliferative activity within the $\mathrm{CD} 19^{-} \mathrm{CD} 34^{+}$cell compartment.

Leukemic cell proliferation was mainly found in the CD19 ${ }^{+}$ compartment containing $\sim 97-99 \%$ of all leukemic cells. Interestingly, CD19 antigen expression was not uniform, but cell cycle dependent with an increase in fluorescence intensity 
from the G1/early S phase to the G2/M phase of the cell cycle. For kinetic investigations of the small compartment of CD19blast cells, it was crucial to eliminate normal residual hematopoietic cells. We could show that most of the proliferative activity within the $\mathrm{CD} 19^{-}$cell compartment was due to residual myeloid cells and erythroblasts. The remaining $\mathrm{CD} 19^{-}$leukemic cells showed a very low proliferation rate. By subdividing the $\mathrm{CD} 19^{-}$blast cell population according to the expression of the CD34 or CD10 antigen, it could be shown that the BrdU-LI of negative cells was significantly lower than the BrdU-LI of cells expressing either CD34 or CD10 antigen. It has to be mentioned, however, that only the expression of the CD10 antigen is related to the stage of maturation, whereas CD34 expression might also be related to cell cycling (7). Therefore, in pediatric BCP-ALL, the hierarchical structure of the leukemic cell clone defined by immunophenotypic maturation is reflected by the proliferative behavior of the leukemic cells. The proliferative activity of blast cells ranges from more or less quiescence in the most immature immunophenotypes to the well-known proliferation pattern in the mature $\mathrm{CD} 19^{+}$leukemic cells. Because no patient relapsed so far, we could not compare proliferative characteristics at diagnosis and in relapse. Results obtained from one patient with BCP-ALL investigated only at hematologic relapse would suggest exactly the same proliferative behavior of the different blast cell populations as in untreated BCP-ALL.

LSCs in pediatric BCP-ALL are usually defined either by xenotransplantation experiments or by long-term proliferation assays in vitro. Recent publications on the immunophenotype of LSCs detected by these methods are very controversial. Some authors find LSC to reside among immature CD19ALL cells only, whereas others find them to reside within blast cell populations of different stages of immunophenotypic maturation or among $\mathrm{CD} 19^{+} \mathrm{CD} 34^{+} \mathrm{CD} 38^{\text {low }}$ leukemic blast cell populations $(8-12)$. In this context, the definition of LSC by xenotransplantation experiments has to be critically discussed. So far, there is no proof that stem cell activity of ALL cells detected by transplantation into different immunodeficient mouse strains equals leukemia-initiating capacity in a clinical setting. In addition, by flow cytometric analysis of pediatric B-lineage ALL, a candidate LSC population with the phenotype $\mathrm{CD} 19^{+} \mathrm{CD} 34^{+} \mathrm{CD} 38^{\text {low }}$ was not detectable in $40 \%$ of diagnostic and $40 \%$ of minimal residual disease positive samples (13). Therefore, at least in a substantial proportion of B-lineage ALL, the immunophenotype of LSCs would not correspond to $\mathrm{CD} 19^{+} \mathrm{CD} 34^{+} \mathrm{CD} 38^{\text {low }}$ cells. Another recent publication reported an association between the frequency of immature leukemic cells, defined by the phenotype $\mathrm{CD} 34^{+} \mathrm{CD}_{3}{ }^{-}$(the presence or absence of the CD19 antigen was not reported), and the level of minimal residual disease after induction therapy in ALL and, therefore, with prognosis (14). Here, for the first time we show that in BCP-ALL, a small compartment of primitive CD19- leukemic cells with a very low proliferative activity can be found. Therefore, these cells, proven to be leukemic by FISH analysis in two ETV6/ RUNX1 positive cases, show a proliferative behavior like a stem/progenitor cell population. However, additional experiments including xenotransplantation studies have to prove a stem/progenitor cell function of this blast cell compartment. Recent investigations looking at genome-wide DNA copy number abnormalities in untreated BCP-ALL detected a striking genetic variability and subclonal diversity $(15,16)$. In addition, it was shown that relapsing ALL can originate in genetically defined subclones that were either dominant or existed only as a minor subpopulation at the time of initial diagnosis and that more than $50 \%$ of relapses demonstrated a clonal evolution from ancestral clones (17). This suggests a genetic heterogeneity of LSC in ALL. Looking at the stage of immunophenotypic maturation when this genetic diversity is generated would help to define the immunophenotype of leukemia stem cells.

To get some insight in the growth characteristics of the leukemic cell populations at different stages of immunophenotypic maturation, kinetic calculations based on values for DNA synthesis time and apoptotic rate in BCP-ALL described earlier $(5,6)$ were performed. Our data suggest that the continuous expansion of the leukemic cell population in untreated BCP-ALL is exclusively based on the proliferative activity of $\mathrm{CD} 19^{+}$blast cells. The low proliferative activity of immature CD19- blast cells contributes only to maintaining the size of this cell population but not to expanding the total leukemic cell population, a feature suggesting a stem cell/progenitor cell function.

In conclusion, it is shown that in pediatric $\mathrm{CD} 19^{+} \mathrm{BCP}-$ ALL, small numbers of immature $\mathrm{CD} 19^{-}$leukemic cells can be detected that are essentially nonproliferating, a feature shared with hematopoietic stem/progenitor cells. Whether this proliferative quiescence indeed reflects a stem/progenitor cell function has to be investigated in additional xenotransplantation experiments. The difference in the proliferative behavior of leukemic cells at various levels of immunophenotypic maturation may be also of clinical relevance. Because an antiproliferation-based chemotherapy would mainly affect the more mature, actively proliferating $\mathrm{CD} 19^{+}$blast cells, primitive, nonproliferating blast cells might have a higher chance to survive and subsequently contribute to ALL relapse.

\section{REFERENCES}

1. Hystad ME, Myklebust JH, Bø TH, Sivertsen EA, Rian E, Forfang L, Munthe E, Rosenwald A, Chiorazzi M, Jonassen I, Staudt LM, Smeland EB 2007 Characterization of early stages of human B cell development by gene expression profiling. J Immunol 179:3662-3671

2. Cobaleda C, Sanchez-Gárcía I 2009 B-cell acute lymphoblastic leukaemia: towards understanding its cellular origin. Bioessays 31:600-609

3. Moir DJ, Ghosh AK, Abdulaziz Z, Knight PM, Mason DY 1983 Immunoenzymatic staining of haematological samples with monoclonal antibodies. Br J Haematol 55:395-410

4. Zarkowska T, Sally U, Harlow E, Mittnacht S 1997 Monoclonal antibodies specific for underphosphorylated retinoblastoma protein identify a cell cycle regulated phosphorylation site targeted by CDKs. Oncogene 14:249-254

5. Hirt A, Werren EM, Luethy Ridolfi A, Gerdes J, Wagner HP 1992 Cell cycle analysis in lymphoid neoplasia of childhood: differences among immunologic subtypes and similarities in the proliferation of normal and leukaemic precursor B cells. Br J Haematol 80:189-193

6. Hirt A, Leibundgut K, Lüthy Ridolfi A, von der Weid N, Wagner HP 1997 Cell birth and death in childhood acute lymphoblastic leukaemia: how fast does the neoplastic cell clone expand? Br J Haematol 98:999-1001

7. Furness SG, McNagny K 2006 Beyond mere markers: functions for CD34 family of sialomucins in hematopoiesis. Immunol Res 34:13-32

8. Castor A, Nilsson L, Åstrand-Grundström I, Buitenhuis M, Ramirez C, Anderson K, Strömbeck B, Garwicz S, Békássy AN, Schmiegelow K, Lausen B, Hokland P, Lehmann S, Juliusson G, Johansson B, Jacobsen SE 2005 Distinct patterns of hematopoietic stem cell involvement in acute lymphoblastic leukemia. Nat Med 11:630-637 
9. Cox CV, Diamanti P, Evely RS, Kearns PR, Blair A 2009 Expression of CD133 on leukemia-initiating cells in childhood ALL. Blood 113:3287-3296

10. Hotfilder M, Röttgers S, Rosemann A, Schrauder A, Schrappe M, Pieters R, Jürgens H, Harbott J, Vormoor J 2005 Leukemic stem cells in childhood high-risk ALL/ $\mathrm{t}(9 ; 22)$ and $\mathrm{t}(4 ; 11)$ are present in primitive lymphoid restricted $\mathrm{CD} 34^{+} \mathrm{CD} 19^{-}$cells. Cancer Res 65:1442-1449

11. le Viseur C, Hotfilder M, Bomken S, Wilson K, Röttgers S, Schrauder A, Rosemann A, Irving J, Stam RW, Shultz LD, Harbott J, Jürgens H, Schrappe M, Pieters R, Vormoor J 2008 In childhood acute lymphoblastic leukemia, blasts at different stages of immunophenotypic maturation have stem cell properties. Cancer Cell 8:47-58

12. Kong Y, Yoshida S, Saito Y, Doi T, Nagatoshi Y, Fukata M, Saito N, Yang SM, Iwamoto C, Okamura J, Liu KY, Huang XJ, Lu DP, Shultz LD, Harada M, Ishikawa F $2008 \mathrm{CD} 4^{+} \mathrm{CD} 38^{+} \mathrm{CD} 19^{+}$as well as $\mathrm{CD} 34^{+} \mathrm{CD} 38^{-} \mathrm{CD} 19^{+}$cells are leukemiainitiating cells with self-renewal capacity in human B-precursor ALL. Leukemia 22:1207-1213

13. Wilson K, Case M, Minto L, Bailey S, Brown N, Jesson J, Lawson S, Vormoor J, Irving J 2010 Flow minimal residual disease monitoring of candidate leukemic stem cells defined by the immunophenotype, $\mathrm{CD} 34^{+} \mathrm{CD} 38$ lowCD $19^{+}$in B-lineage childhood acute lymphoblastic leukemia. Haematologica 95:679-683

14. Ebinger M, Witte KE, Ahlers J, Schäfer I, André M, Kerst G, Scheel-Walter HG, Lang P, Handgretinger R 2010 High frequency of immature cells at diagnosis predicts high minimal residual disease level in childhood acute lymphoblastic leukemia. Leuk Res 34:1139-1142

15. Greaves M 2009 Darwin and evolutionary tales in leukemia. Hematology Am Soc Hematol Educ Program 3-12

16. Bateman CM, Colman SM, Chaplin T, Young BD, Eden TO, Bhakta M, Gratias EJ, van Wering ER, Cazzaniga G, Harrison CJ, Hain R, Ancliff P, Ford AM, Kearney L, Greaves M 2010 Acquisition of genome-wide copy number alterations in monozygotic twins with acute lymphoblastic leukemia. Blood $115: 3553-3558$

17. Mullighan CG, Phillips LA, Su X, Ma J, Miller CB, Shurtleff SA, Downing JR 2008 Genomic analysis of the clonal origin of relapsed acute lymphoblastic leukemia. Science 322:1377-1380 